\title{
ポリマー系ナノコンポジット材料の開発動向 一オレフィン，ポリスチレン系—
}

\section{1.はじめに}

粘土鉱物のひとつに，モンモリロナイトと呼ばれるもの がある.モンモリロナイトの結晶構造は, 図 1 に示すよう に，シリカ四面体層/アルミナ八面体層/シリカ四面体層か らなる基本単位層（以下，シリケート層とよぶ）が積層し てなる、このシリケート層は厚さが約 $1 \mathrm{~nm}$, 一辺の長さ が $100 \mathrm{~nm}$ のシート状をしている. シリケート層の大きさ を, 樹脂の補強材として用いられるガラス繊維一本と比較 すると, 厚さで約 $10^{4}$ 分の 1 , 長さで約 $10^{3}$ 分の 1 と非常 に小さい。このシリケート層を合成樹脂中にばらばらにし て均一に分散させた複合材料が近年注目されているポリ マー系ナノコンポジット材料である. ポリマー系ナノコン ポジット材料としては, ナイロン系 (ナイロン $6^{1) \sim 4)}$, ナ イロン $66^{5}$ 等), ポリオレフィン系 (ポリプロピレン6) 8), ポリエチレン 等), ポリスチレン樹脂 ${ }^{10)}$, エポキシ樹脂 ${ }^{11}$, ポリカプロラクトン ${ }^{12)}$ な゙が知られている.

モンモリロナイトは, 図 1 に示すように, シリケート層 を構成するアルミナ八面体層の中心にある 3 価のアルミニ ウムイオン $\left(\mathrm{Al}^{3+}\right)$ の一部が，ほぼイオン半径が等しい 2 価 のマグネシウムイオン $\left(\mathrm{Mg}^{2+}\right)$ に置換されている.このた

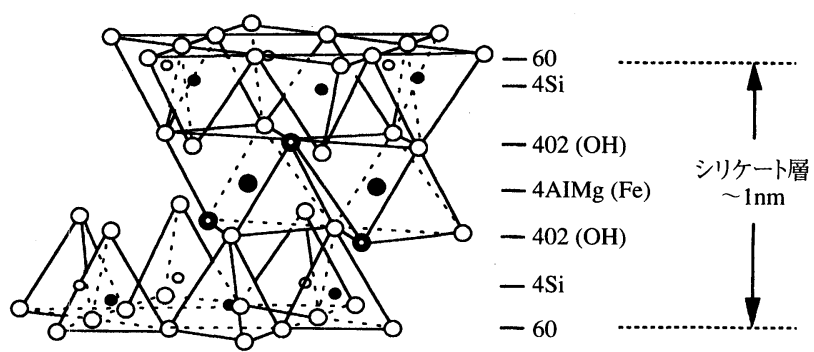

交換性カチオン

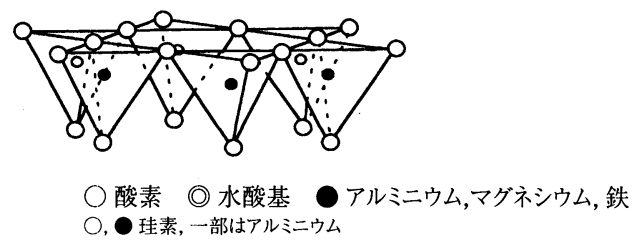

図 1 モンモリロナイトの構造

* Kato, Makoto/Usuki, Arimitsu

(侏豊田中央研究所 有機材料研究室

愛知県長久手町（T 480-1192）

2002.3.14 受理
加 藤 誠*

め，シリケート層ではプラス電荷が不足し，電荷を補償す るためにシリケート層の層間にナトリウムイオン $\left(\mathrm{Na}^{+}\right)$な どの陽イオンが存在している。この陽イオンは交換性陽イ オンと呼ばれ，他の陽イオンを含んだ溶液にモンモリロナ イトを分散させると，直ちにイオン交換反応が生じる。こ のイオン交換反応を利用して，アルキルアンモニウム塩な どの有機カチオンをモンモリロナイトの層間にインターカ レーションさせ，層間化合物を形成させることができる.

\section{2.ナイロン 6-クレイハイブリッド}

インターカレーション機能を利用して，世界ではじめて 工業化された材料がナイロン 6 のナノコンポジット材料 (ナイロン 6-クレイハイブリッド, Nylon 6-Clay Hybrid:

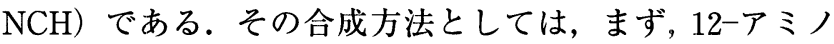
ドデカン酸 $\left(\mathrm{H}_{2} \mathrm{~N}\left(\mathrm{CH}_{2}\right)_{11} \mathrm{COOH}\right)$ のアンモニウム塩でモン モリロナイトの層間のナトリウムイオンをイオン交換する. 得られた層間化合物をナイロン 6 のモノマーである $\varepsilon-カ$ プロラクタムと混合し, $\varepsilon$ ーカプロラクタムを溶融（融点： $\left.70^{\circ} \mathrm{C}\right)$ させることによって, モンモリロナイトの層間にイ ンターカレートさせる ${ }^{1)}$. 最後に, $\varepsilon$ 一カプロラクタムを約 $250^{\circ} \mathrm{C}$ で開環重合させると，重合の進行とともに層間は大 きく広がり（100Å以上），ナイロン 6 中にモンモリロナイ トのシリケート層が均一に分散した $\mathrm{NCH}$ が得られる その重合概念図を図 2 に示す.

$\mathrm{NCH}$ を透過型電子顕微鏡で観察すると, 図 3 に示すよ うに，黒く繊維状のものが多く見える.これらがモンモリ ロナイトのシリケート層の断面であり, ナイロン 6 のマト リクス中に均一に分散している。 なお，モンモリロナイト をそのままナイロン 6 と溶融・混練しても層構造は保持し たままで分散し，このようなナノコンポジット材料は得ら れない。層構造が保持したまま分散したこのような材料を ナイロン 6-クレイコンポジット（Nylon 6-Clay Composite : NCC）と呼び, NCH とは区別している.

表 1 に NCH の特性 ${ }^{3}$ を NCC およびナイロン 6 と比較し て示す. NCH は，モンモリロナイトのわずか $4.2 \%$ の添 加で, ナイロン 6 に比べ引張強さで約 1.5 倍, 弾性率で約 2 倍の值を示している. また, 熱変形温度は $152^{\circ} \mathrm{C}$ を示し, ナイロン 6 に比べ約 $80^{\circ} \mathrm{C}$ の向上が認められる. NCCでも 熱変形温度はナイロン 6 に比べ改善されるが，他の特性は モンモリロナイトを混合するとむしろ低下している。また， このような特性の改善を通常の無機フィラーで行おうとす 


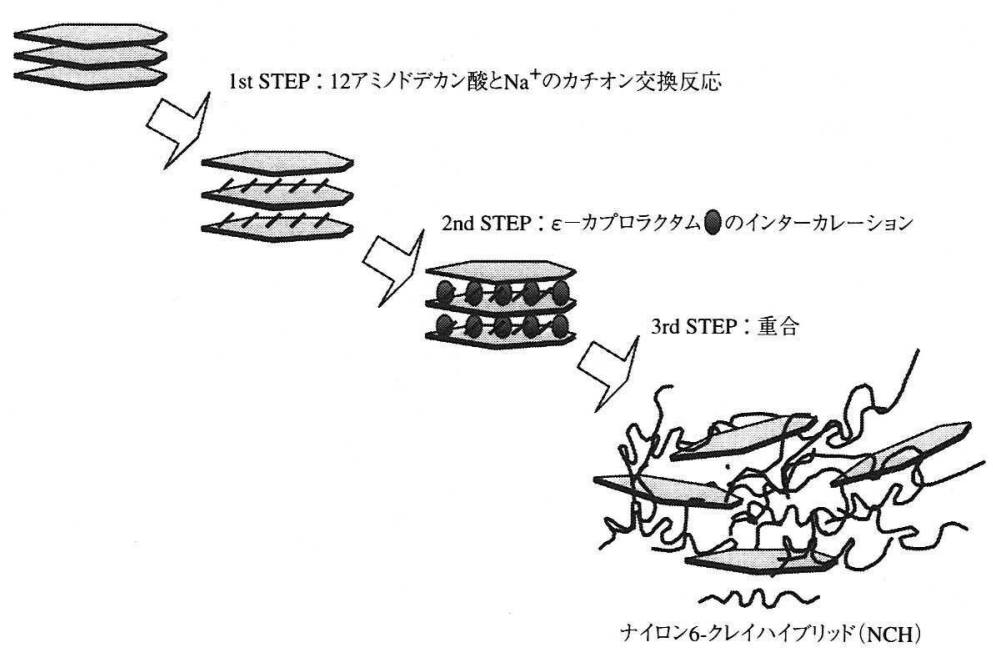

図 2 ナイロン 6-クレイハイブリッドの合成方法（概念図）

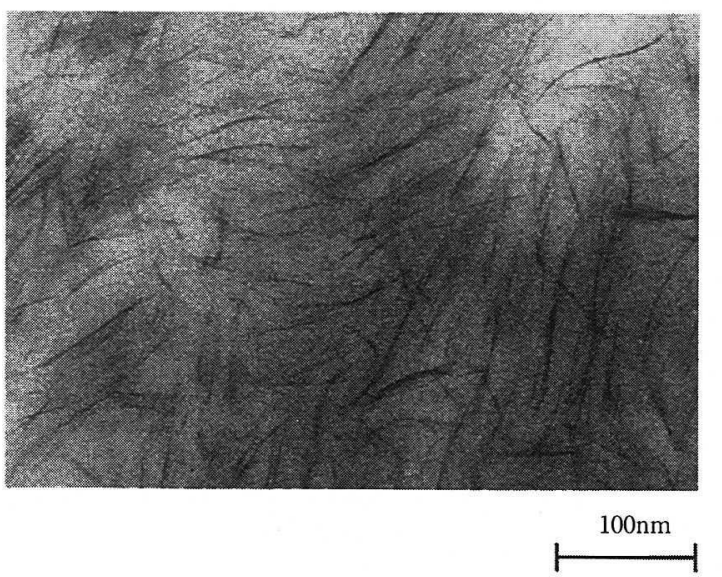

図 3 シリケート層の分散状態（TEM 観察写真, モンモ リロナイト $5 \mathrm{wt} \%$ 含有)

表 1 NCH の特性

\begin{tabular}{l|ccc}
\hline \multirow{2}{*}{ 項 目 } & \multicolumn{3}{|c}{ 試 } \\
\cline { 2 - 4 } & $\mathrm{NCH}$ & $\mathrm{NCC}$ & Nylon 6 \\
\hline モンモリロナイト含有量 $(\mathrm{wt} \%)$ & 4.2 & 5.0 & 0 \\
\hline 引張強度 $(\mathrm{MPa})$ & 107 & 61 & 69 \\
\hline 引張弾性率 $(\mathrm{GPa})$ & 2.1 & 1.0 & 1.1 \\
\hline シャルヒヒー衝撃強さ $\left(\mathrm{KJ} / \mathrm{m}^{2}\right)$ & 6.1 & 5.9 & 6.2 \\
\hline 熱変形温度 $\left({ }^{\circ} \mathrm{C}\right)$ & 152 & 89 & 65 \\
\hline 吸水率 $\left(23^{\circ} \mathrm{C}, 24 \mathrm{hr}, \%\right)$ & 0.51 & 0.90 & 0.87 \\
\hline モンモリロナイトの層間距離 $(\AA)$ & 200 & 12 & - \\
\hline
\end{tabular}

ると $30 \%$ 以上の添加が必要である. その際, 衝撃強さが 低下するが，NCH では衝撃強さの低下はほとんど認めら れない.すなわち,これらの特性の大幅な改善は, モンモリ ロナイトのシリケート層が分子サイズのフィラーとしてナ イロン 6 のマトリクス中に均一に分散された結果と言える. $\mathrm{NCH}$ の疲労特性（ひずみ振幅と疲労寿命の関係）につ いて図 4 に示す. ガラス瀻維はナイロン 6 の補強として広 く用いられているが, ナイロン 6 との弾性率の差が大きく， 繰り返し変形を行った場合, ガラス瀻維ーナイロン 6 界面 での応力集中が生じやすい。 そのために疲労強度が十分で ない場合がある、 $\mathrm{NCH}$ (モンモリロナイト $2 \mathrm{wt} \%$ 含有）と

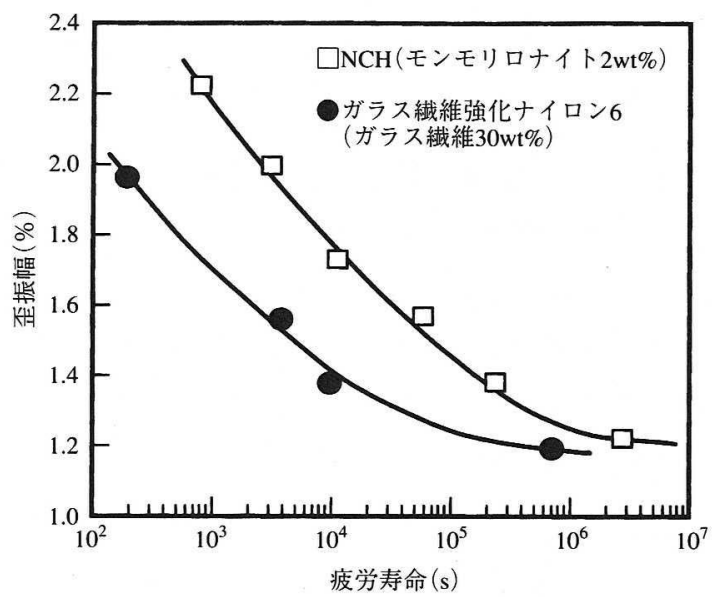

図 $4 \mathrm{NCH}$ とガラス繊維強化ナイロンの疲労特性の比較

ガラス繊維強化ナイロン 6（ガラス緘維 30\% 配合）の疲 労寿命の比較では, NCH がガラス緘維強化ナイロン 6 に 比べ長くなる。両者の弾性率はほぼ等しいものの, $\mathrm{NCH}$ の疲労寿命が長いのは, シリケート層とナイロン 6 の界面 がイオン結合されて強固であり，しかもシリケート層が分 子状に分散しているために応力集中源が少ないためと考察 されている ${ }^{13)}$.

\section{3. ポリプロピレン-クレイハイブリッド}

ポリプロピレンは, バンパーやインスッルメントパネル 等で使用され，自動車分野で多く使用されているポリオレ フィン材料である. その合成は, 高度に設計された触媒を 用いて, もっぱら気相反応で行なわれている. そのため, ポリプロピレンークレイハイブリッド $(\mathrm{PPCH})$ の合成に は，NCHのようにモノマーを層間で重合する方法の適用 は極めて難しい，極性のある変性ポリプロピレンをモンモ リロナイトとポリプロピレンの相溶化郕として用いて $\mathrm{PPCH}$ の合成がはじめて可能となった た $^{6 / 8)}$. 図 5 に $\mathrm{PPCH}$ の合成について概念図で示す．有機化したモンモリロナイ トの層間に, 無水マレイン酸で変性したポリプロピレンが, 無水マレイン酸とシリケート層の水素結合によって, イン ターカレートされる．インターカレートによってできた層 間化合物は層間が拡大し, 層と層の結合力は弱められてい 
る.この層間化合物が高いせん断力のもとにポリプロピレ ンと混練されるとポリプロピレンが層間にさらにインター カレートされ, 結果としてシリケート層が一枚一枚剥離し た状態で分散される。表 2 には，異なる変性 PP (PP-Ma1010, PP-Ma 1001）を用いた PPCH 2 種類の粘弾性測定 の結果をポリプロピレンークレイコンポジット (PPCC) と それぞれのベース PP の結果 ${ }^{8}$ ともに示してある。いず れの PPCH もわずか 4.8 wt\%のモンモリロナイトの添加 で, PP や変性 PP の融点付近である $140^{\circ} \mathrm{C}$ を除き, PPに
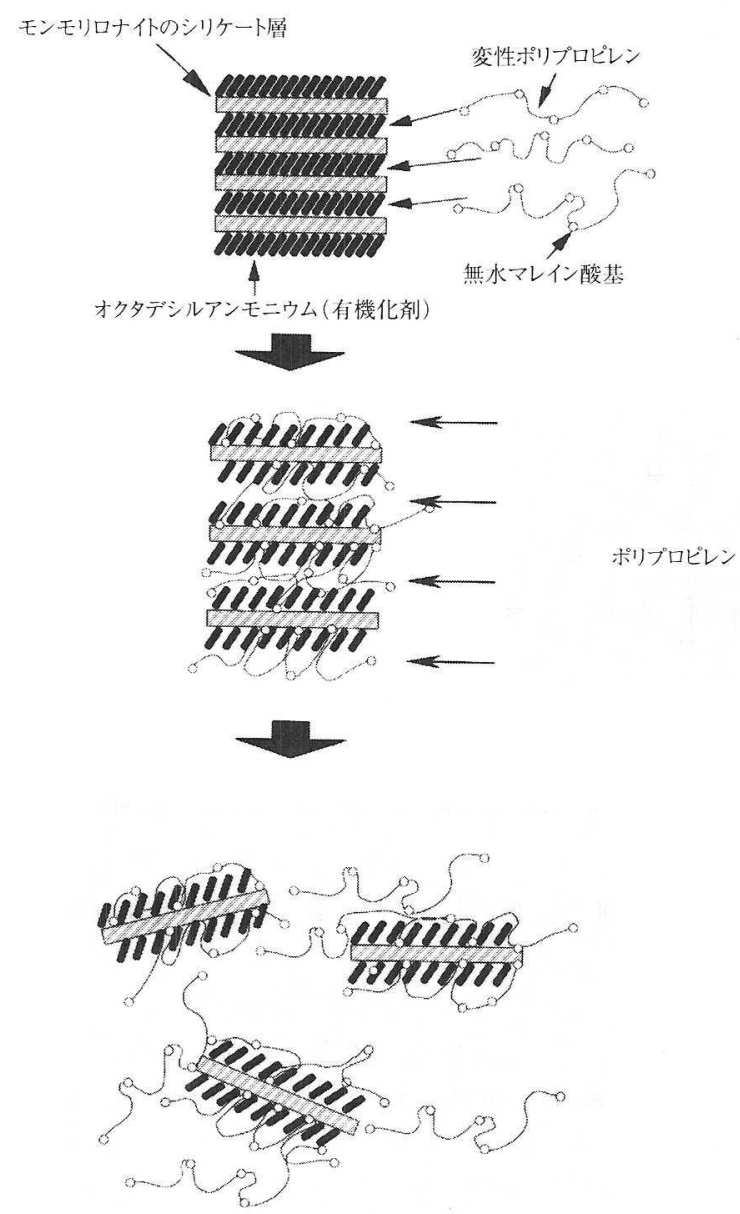

図 5 ポリプロピレン-クレイハイブリッド合成方法 (概念図)
比べて 1.3 1.6 倍の高い弾性率を示している.これらの 高い弾性率は, シリケート層がナノメートルオーダーで分 散していないPPCCでは得ることができない. 2 種類の $\mathrm{PPCH}$ で比較すると,わずかに PP-Ma-1001を用いた $\mathrm{PPCH}$ の弾性率の方が, PP-Ma-1010を用いた PPCH に比 べ, 高い。これは，マトリクスの PP と変性 PP の相溶性 に差があるためである。PP-Ma-1010の変性度は酸価で 52 $\mathrm{mgKOH} / \mathrm{g}$ であり, PP-Ma-1001の酸価 $26 \mathrm{mgKOH} / \mathrm{g}$ に 比べ，2 倍ほど高い。極性の低いPP-Ma-1001 はPP と相 溶性が高く, シリケート層を PP 中に効率よく分散でき, 補強效果が高くなる。

ポリプロピレンークレイハイブリッド（PPCH）につい て，最近，新しい知見が得られた ${ }^{14,15)}$ 。自動車や航空機な どの軽量化やプラスチック材料自体の減量の面から発泡成 形が注目されている. 特に従来の発泡剂を使う化学発泡に 代り, 超臨界 $\mathrm{CO}_{2}$ による発泡は盛んに研究開発が行われ ている。 $\mathrm{PPCH}$ を超臨界 $\mathrm{CO}_{2}$ で発泡成形すると, $\mathrm{PP}$ 単独 に比べ, 発泡セルの大きさが小さくなることがわかった(図 6).さらにクレイのシリケート層がセル壁に対して平行に 配行して並び, さらにその内側では電気的な反発によって シリケート層がカードハウス構造（トランプのカードを積 み上げる，あるいは箱を作る場合にできる構造）を形成す ることがわかった（図 7)。発泡成形では，発泡によって 成形体の強度が低下するのが問題となる。強度低下を防ぐ にはセル径を小さくすることや補強材の添加が有効である

表 2 PP-クレイハイブリッドの粘弾性特性

\begin{tabular}{|c|c|c|c|c|c|}
\hline \multirow{2}{*}{ 材 料 } & \multicolumn{4}{|c|}{ 睁蔵弾性率, ${ }^{\circ} \mathrm{GPa}$} & \multirow{2}{*}{$\mathrm{Tg},{ }^{\circ} \mathrm{C}$} \\
\hline & $-40^{\circ} \mathrm{C}$ & $20^{\circ} \mathrm{C}$ & $80^{\circ} \mathrm{C}$ & $140^{\circ} \mathrm{C}$ & \\
\hline $\begin{array}{l}\mathrm{PPCH} / \mathrm{PP}-\mathrm{Ma}-1010 \\
\text { クレイ } 4.8 \mathrm{wt} \% \text { \%含有 }\end{array}$ & $5.15(1.31)$ & $3.12(1.58)$ & $1.03(1.59)$ & $0.13(0.60)$ & 11 \\
\hline $\begin{array}{l}\mathrm{PPCH} / \mathrm{PP}-\mathrm{Ma}-1001 \\
\text { クレイ } 4.8 \mathrm{wt} \% \text { 含有 }\end{array}$ & $5.26(1.34)$ & $3.09(1.56)$ & $1.10(1.70)$ & $0.21(0.94)$ & 8 \\
\hline $\begin{array}{c}\operatorname{PPCC}(\text { コポジット) } \\
\text { クレイ } 4.8 \mathrm{wt} \% \text { \%含有 }\end{array}$ & 4. $50(1.15)$ & $2.36(1.19)$ & $0.82(1.26)$ & $0.28(1.25)$ & 9 \\
\hline PP/PP-Ma-1010 & $3.92(1.00)$ & $1.99(1.01)$ & $0.60(0.92)$ & $0.15(0.68)$ & 13 \\
\hline PP/PP-Ma-1001 & $4.04(1.03)$ & $2.02(1.02)$ & $0.55(0.85)$ & $0.14(0.62)$ & 10 \\
\hline PP & 3.92 & 1.98 & 0.65 & 0.22 & 13 \\
\hline
\end{tabular}

"（）内の数值はそれぞれのベースのPP と比較した值.

"ガラス転移温度は, $\tan \delta$ から求めたもの.

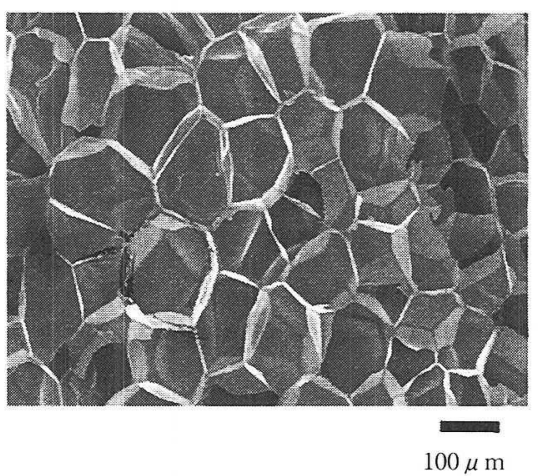

(b) ポリプロピレン単体

(a) ポリプロピレンノクレイハイブリッド

図 6 ポリプロピレン-クレイハイブリッドの発泡セル

$\left(\mathrm{SEM}\right.$ 観察, $\mathrm{CO}_{2}$ 発泡, 発泡温度 $139.2^{\circ} \mathrm{C}$ ) 


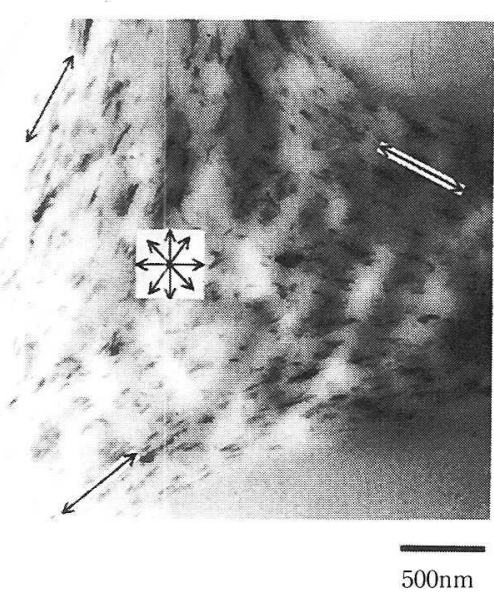

(a) セルの結合部位

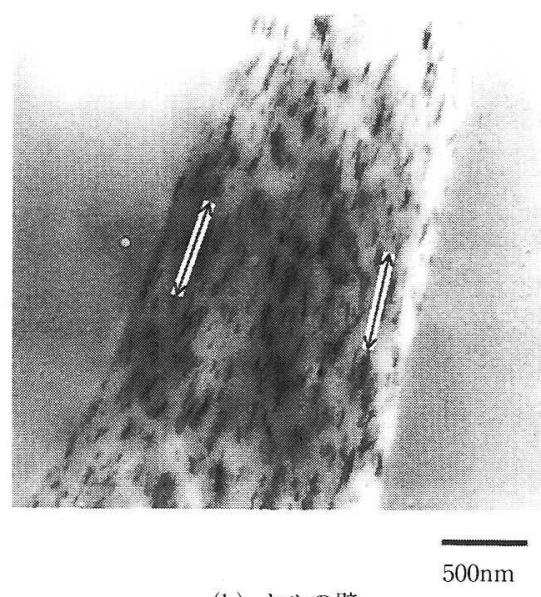

(b) セルの壁

図 7 ポリプロピレン-クレイハイブリッドの発泡セル

(TEM 観察, $\mathrm{CO}_{2}$ 発泡, 発泡温度 $134.7^{\circ} \mathrm{C}$, クレイ $4 \%$ 添加)

表 3 ポリスチレンークレイハイブリッドの引張特性

\begin{tabular}{|c|c|c|c|c|c|}
\hline \multirow[b]{2}{*}{ 試 料 } & \multirow{2}{*}{$\begin{array}{c}\text { PS/PSoz } \\
\text { の比率 }\end{array}$} & \multirow{2}{*}{$\begin{array}{c}\text { クレイ含有量 } \\
\text { (wt\%) }\end{array}$} & \multicolumn{3}{|c|}{ 引張特性 ${ }^{b}$} \\
\hline & & & $\begin{array}{c}\text { 张張弾性率 } \\
(\mathrm{MPa})\end{array}$ & $\begin{array}{c}\text { 引張強度 } \\
(\mathrm{MPa})\end{array}$ & $\begin{array}{l}\text { 伸び } \\
(\%)\end{array}$ \\
\hline PSCH-1 & $0 / 100$ & 4.8 & $1.78(1.38)$ & $38.3(0.82)$ & 2.3 \\
\hline PSCH-2 & $50 / 50$ & 4.7 & $1.74(1.33)$ & $38.7(0.91)$ & 2.4 \\
\hline $\operatorname{PSCC}($ コンホ洲) & $100 / 0$ & 4.4 & $1.40(1.09)$ & $44.0(0.90)$ & 4.1 \\
\hline PSoz & $0 / 100$ & 0 & 1.29 & 46.5 & 4.0 \\
\hline PS/PSoz & $50 / 50$ & 0 & 1.30 & 42.7 & 3.5 \\
\hline PS & $100 / 0$ & 0 & 1.30 & 48.9 & 5.6 \\
\hline
\end{tabular}

"PS はポリスチレン, PSozはオキサゾリン変性ポリスチレンを示す.

b（）内の值はそれぞれのベースのマトリックスと比較した相対值を示す。

が実際には難しい.PPCH では添加したクレイによるセル 径の制御やシリケート層のセル壁内あるいはセル結合部位 での構造形成によって強度低下が抑えられる可能性がある。

\section{4.ポリスチレンークレイハイブリッド}

ポリプロピレンークレイハイブリッドで得られた知見に よって，オキサゾリン変性したポリスチレンを用いてポリ スチレンークレイハイブリッドが合成されている到。表 3 にポリスチレンークレイハイブリッドの引張特性を示す. モンモリロナイトの添加量は 4.7 4.8 wt \%である. ポリ スチレンークレイハイブリッドの弾性率は, マトリクスの オキサゾリン変性ポリスチレンやオキサゾリン変性ポリス チレン/ポリスチレンマトリクスの弾性率にくらべ, 約 1.3 ～1. 4 倍に高くなっている. 一方，クレイがハイブリッド 化していないポリスチレンークレイコンポジット（PSCC) では，弾性率の向上は約 1.1 倍でしかない。

\section{5.まとめ}

このように，ポリマー系ナノコンポジットの特徴は，わ ずか数 wt\%のモンモリロナイトの添加によって大きく強 度，剛性が向上する点にある。これらの向上により，薄肉 化や充填材の減量による成形品の軽量化が期待できる。 た, 数 wt\%しか添加されていないので, 成形品の表面外 観品質も損なわないという魅力も合わせ持っている.

\section{参 考 文 献}

1) Usuki, A., Kojima, Y., Kawasumi, M., Okada, A., Kurauchi, T. and Kamigaito, O.: J. Mat. Res. 8 (5), 1174 (1993)

2 ) Usuki, A., Kojima, Y., Kawasumi, M., Okada, A., Kurauchi, T. and Kamigaito, O.: J. Mat. Res. 8 (5), 1179 (1993)

3 ) Kurauchi, T.,Okada, A., Nomura, T.,Nishio, T., Saegusa, S. and Deguchi, R. : SAE Paper Series 910584

4 ) Kojima, Y.,Usuki, A., Kawasumi, M.,Okada, A., Kurauchi, T. and Kamigaito, O. : J. Appl. Polym. Sci., 49, 1259 (1993)

5 ) Kato, M., Okamoto, H., Hasegawa, N., Usuki, A. Sato, N., : Proc. $6^{\text {th }}$ Japan International SAMPE Symposium, 2, 693 (1999)

6 ) Kato, M., Usuki, A., Okada, A. : J. Appl. Polym. Sci., 66, 1781 (1997)

7 ) Hasegawa, N., Kawasumi, M., Kato, M., Usuki, A. and Okada, A. : J. Appl. Polym. Sci., 67, 87 (1998)

8 ) Kawasumi, M., Hasegawa, N., Kato, M.,Usuki, A. and Okada, A. : Macromolecules, 30(20), 6333 (1997)

9 ) Hasegawa, N., Okamoto, H., Kato, M., Usuki, A. : J. Appl. Polym. Sci., 78, 1918 (2000)

10) Hasegawa, N., Okamoto, H., Kawasumi, M. and Usuki, A. : J. Appl. Polym. Sci., 74, 87 (1999)

11) Lan, T. and Pinnavaia, T. J. : Chem. Mater. 6, 2216 (1994)

12) Messersmith, P. B. and Giannelis, E. P. : J. Polym. Sci. A, Polym. Chem.33(7) 1047 (1995)

13）山下敦志, 高原 淳, 梶山千里：日本レオロジー学会 誌, 24(3)，117 (1996)

14) Nam P. H., Maiti P., Okamoto M., Kotaka T., Takada M., Ohdhima M. and Usuki A. : Polymer, 42, 9633 (2001) submitted

15) Okamoto M., Nam P. H., Maiti P., Kotaka T., Hasegawa, N. and Usuki, A. : Nanoletter, 1, 503 (2001) 